\title{
Global Public Health, Global Problems
}

\author{
Benjamin Ruiz Loyola* \\ Faculty of Chemistry, UNAM, Mexico \\ *Corresponding author: Benjamin Ruiz Loyola, Faculty of Chemistry, UNAM, Mexico
}

\begin{tabular}{|c|c|}
\hline ARTICLE INFO & ABSTRACT \\
\hline Received: 亚 November 05, 2019 & Citation: Benjamin Ruiz Loyola. Global Public Health, Global Problems. Biomed J Sci \& \\
\hline Published: 慧 November 13, 2019 & Tech Res 22(5)-2019. BJSTR. MS.ID.003808. \\
\hline
\end{tabular}

\section{Introduction}

Humans grouped into communities to protect themselves from the consequences of natural disasters and the presence of predators, whether they were animals or groups of humans who attacked them to enslave them, strip them of food, steal their lands or appropriate women to reproduce. Eventually those communities created governments to maintain internal order and agreed to pay a portion of their income (whether in kind, with part of the product of their labor, or with money, for so-called taxes) in order to obtain, from their leaders, security and services fundamentally. Services include, of course, everything concerning health. Public health has been altered by the effect of globalization. Diseases that previously could be limited to certain specific areas, nowadays they spread in less time and in greater territorial extension. The risks presented by diseases such as SARS, bird flu, AH1N1 influenza are examples. In this way, health problems affect everyone, to a greater or lesser extent, literally understood. Medical, pharmacological, epidemiological, biomedical and other types of research, whether to develop new medications, vaccines or prophylactic or diagnostic methods, are of the greatest importance, regardless of where they are carried out, so that their progress and results concern us, all the inhabitants of the planet.

Any work that allows us to know more in depth the mechanisms of transmission and contagion of viruses, the development of rapid and accurate identification techniques as well as new and better antiviral drugs, will allow the world to face a pandemic (one that certainly has been long-awaited) that, eventually, could have the dissemination characteristics of the influenza AH1N1 of 2009, with the death rate of bird flu, that is, be prepared for a situation similar to that experienced in 1918 (mainly), with the so-called Spanish flu (which was originated in the United States). The pandemic originated in a US army camp in Kansas in March 1918 ; it spread throughout the United States and fourteen days later a new outbreak appeared in other camps. The soldier's trip to Europe to participate in World War I brought the flu to the old continent and spread rapidly throughout the world. The most affected were young people between 20 and 40 years old and women were more susceptible to the disease. It is estimated that the total deaths reached $50,000,000$ worldwide and among the most affected countries were Mexico and Guatemala.

\section{Now}

Since the discovery of penicillin, antibiotics have been an important weapon in the fight against infectious microorganisms and their use has benefited humanity in which deaths and consequences of such diseases have been reduced; Thus, most people have become more long-lived. For this reason, the resistance of microorganisms to antibiotics is an extremely important and, at the same time, alarming health issue. On one hand, antibiotics have been used intensively in this fight against microorganisms; on the other, as they are simpler organisms, their adaptation is faster, so that they have mutated to generate resistance to certain drugs that previously ended them, so that new antimicrobial agents must be developed to control them. This problem has reached a high point when an enzyme was discovered in 2009 that makes the bacteria that possess it, immune to a broad spectrum of antibiotics that have a beta-lactam group in their structure. This enzyme has been called NDM-1 (New Dehli Metalo-beta-lactamase 1, because it was discovered in hospitals in New Dehli). So far it has been limited to in-hospital problems, but that in itself is extremely serious, because people comes to hospitals to relieve themselves, not to get sick. A worrying disease that is resurfacing is tuberculosis (TB). This 
disease is as old as man himself, since human remains from the Neolithic period have been found with the characteristic lesions of it; some Egyptian graves show engravings with people showing the disease.

Hippocrates called it tisis and Aristotle suggested that the cause of the expansion of evil was something that the sick exhaled, affecting those who inhaled the same air as they did. Medications that have been developed to control this condition have generally been very useful, but vaccination has been most valuable. However, certain strains of this disease have been classified as moderately resistant to medications or resistant to combinations of medications (MDR-TB, Multi-Drug Resistant-Tuberculosis). The inappropriate use of antibiotics in tuberculosis therapy (because the doctor prescribes poorly, because the patient does not take the medication as directed or because they abandon the treatment) has caused this resistance (again, the adaptation of the microorganism and its mutation gives that ability) which is a real problem. The WHO reported, in October 2011, that the estimations involved 8.8 million of tuberculosis patients and of those more than 650,000 were MDRTB. WHO expectations were that for 2012 there would be 2,000,000 MDR-TB cases worldwide, triple what was estimated for 2011. And now, in 2019, WHO reports that in 20187 million new cases were notified, and more than 400,000 people developed MDR-TB. And the treatment success rate remains a very low $56 \%$ globally.

And things are worst if MDR-TB and HIV are associated!

Do you want to be more scared? There is a kind of microorganism that is been called TDR-Tuberculosis, or TDR-TB, because it is immune to all antituberculosis drugs already known!

All of the above shows that:

1) Public health is no longer an exclusively local matter; with technological advances in communication, it is possible to move from one place to another in a matter of hours, spreading the diseases, very frequently inadvertently;

2) Respiratory diseases are of great global importance, at least at this start of the 21st century, which requires scientific research not only on the internal structures of the microorganisms that cause and spread them, but also on the ways in which the infections are transmitted and caused, to elaborate the protocols of prevention of the contagion and of answer, in the event that outbreaks appear;

3) The decision to request a shortage on data collection in scientific publications is debatable, at least, because this prevents the globalization of knowledge and encourages it, putting at risk the development of effective sanitary methodologies. Fortunately, this problem was overcome to allow scientific knowledge to be distributed worldwide.

Another important affair that is very actual, deals with the bioterrorism menace. The World Health Organization (WHO) contemplates four specific diseases associated with biological weapons, which are anthrax, botulism, plague and smallpox. However, it is not necessary to use any of these diseases as a key element in a bioterrorist attack. History shows us otherwise. The term terrorism was first used in the year 1795 to refer to the regime established by the Jacobins in post-revolutionary France. It was employed again to call the violence of the Irish against the English owners, in the 19th century, and to qualify the Russian group Narodnaya Volya (the will of the people) that in 1881 ended the life of Tsar Alexander II. Later, terrorism is linked to the actions of anarchist groups, who made extensive use of murder and sabotage for political purposes, a practice they justified as "propaganda for the fact." The term was consolidated with the proliferation of this type of organizations, although it is a literally ambiguous word, because all violence generates social fear, even unprovoked [1].

Some bioterrorist attacks in 20th century are as follows:

a) In September 1931, planes from Japan dropped porcelain bombs with bacterial liquid and flies infected with Yersina Pestis.

b) In 1939 the Japanese polluted the Amur River (China) and its tributaries in order to cause epidemics of typhus and cholera.

c) In 1942 the Japanese, in the war against China, spread the plague bacteria using rats that parachuted, transmitting the human flea (Pulex irritans).

d) In 1984 a religious sect used a Salmonella typhimurium culture to commit a biological attack in an Oregon restaurant, causing more than 750 victims, 45 of whom required hospital admission.

e) The scientists of the Japanese sect AUM SHINRIKYO conducted studies focusing on Bacillus anthracis and botulinum toxin.

f) In 2001 there were cases of pulmonary and cutaneous anthrax detected in Florida, Washington, New York and New Jersey [2].

Without delving deeper into this classic aspect of bioterrorism, we must mention the most recent advances in this field: the imminent appearance of ethnic weapons and genetic weapons, through biotechnology, genetic research and synthetic biology. Although both derive from the genetic manipulation of known microorganisms, they have a fundamental difference: ethnic weapons are programmed to activate by recognizing in their host a particular gene, which may be associated with a specific race, a skin color or eyes, that is, they are highly selective weapons linked to specific genetic markers. Of course, this sounds like science fiction, but it is already discussed in the scientific journals about this type of weaponry. The field of biological terrorism is no more encouraging than that referring to completely natural pandemics [3]. 
Beyond WHO considerations, various authors consider a much longer list of pathogenic organisms that can be used as biological weapons; for example, we will mention
(a) Escherichia coli
(b) Hemophilic influenza
(c) Brucellosis
(d) Tularemia
(e) Malaria
(f) Cholera
(g) Shigella flexneri
(h) Salmonella [4]
(i) Venezuelan equine encephalitis
(j) Typhoid (typhus)
(k) Yellow fever
(l) Q Fever

\section{ISSN: 2574-1241}

DOI: $10.26717 /$ BJSTR.2019.22.003808

Benjamin Ruiz Loyola. Biomed J Sci \& Tech Res

This work is licensed under Creative Commons Attribution 4.0 License

Submission Link: https://biomedres.us/submit-manuscript.php
The importance of expanding the list is that, by resorting again to the imagination and creativity of terrorists, it would be possible not to use to a special pathogen for war, but simply to use those that move freely through each specific region. In conclusion, public health affairs are no longer a local matter but a global one and very sensitive. Now more than ever, the WHO needs to obtain and distribute sanitarian information ASAP; maybe all embassies should have health and sanitary attachés that collaborate to have fast responses to pandemia outberaks.

\section{References}

1. Kenneth I Berns, Arturo Casadevall, Murray L Cohen, Susan A Ehrlich, Lynn W Enquist, et al. (2012) Adaptations of Avian Flu Virus Are a Cause for Concern, Science 335(6069): 660-661.

2. https://extranet.who.int/sree/Reports?op=vs\&path=/WHO_HQ_ Reports/G2/PROD/EXT/MDRTB_Indicators_charts.

3. http://www.who.int/csr/delibepidemics/didease/en/print.html.

4. Appel JM (2009) Is all fair in biological warfare? The controversy over genetically engineered biological weapons. J Med Ethics 35(7): 429-432.

$\begin{array}{ll}\text { BIOMEDICAL } & \text { Assets of Publishing with us } \\ \text { RESEARCHES } & \text { - Global archiving of articles } \\ & \text { - Immediate, unrestricted online access } \\ \end{array}$

